\title{
Composition of Strawberry Floral Volatiles and their Effects on Behavior of Strawberry Blossom Weevil, Anthonomus rubi
}

\author{
Raimondas Mozūraitis ${ }^{1}$ (D) - David Hall ${ }^{2} \cdot$ Nina Trandem $^{3} \cdot$ Baiba Ralle $^{4} \cdot$ Kalle Tunström $^{1} \cdot$ Lene Sigsgaard $^{5}$. \\ Catherine Baroffio ${ }^{6} \cdot$ Michelle Fountain $^{7} \cdot$ Jerry Cross $^{2} \cdot$ Atle Wibe $^{8} \cdot$ Anna-Karin Borg-Karlson $^{9,10}$
}

Received: 15 May 2020 / Revised: 27 August 2020 / Accepted: 28 September 2020 / Published online: 8 October 2020

(C) The Author(s) 2020

\begin{abstract}
The strawberry blossom weevil (SBW), Anthonomus rubi, is a major pest in strawberry fields throughout Europe. Traps baited with aggregation pheromone are used for pest monitoring. However, a more effective lure is needed. For a number of pests, it has been shown that the attractiveness of a pheromone can be enhanced by host plant volatiles. The goal of this study was to explore floral volatile blends of different strawberry species (Fragaria $x$ ananassa and Fragaria vesca) to identify compounds that might be used to improve the attractiveness of existing lures for SBW. Floral emissions of $F$. $x a$. varieties Sonata, Beltran, Korona, and of $F$. vesca, were collected by both solid-phase microextraction (SPME) and dynamic headspace sampling on Tenax. Analysis by gas chromatography/mass spectrometry showed the floral volatiles of $F$. $x$ ananassa. and $F$. vesca were dominated by aromatic compounds and terpenoids, with 4-methoxybenzaldehyde ( $p$-anisaldehyde) and $\alpha$-muurolene the major compounds produced by the two species, respectively. Multi-dimensional scaling analyses separated the blends of the two species and explained differences between $F$. vesca genotypes and, to some degree, variation between $F$. x ananassa varieties In two-choice behavioral tests, SBW preferred odors of flowering strawberry plants to those of non-flowering plants, but weevils did not discriminate between odors from $F$. $x$ ananassa and $F$. vesca flowering plants. Adding blends of six synthetic flower volatiles to non-flowering plants of both species increased the preference of SBW for these over the plants alone. When added individually to non-flowering plants, none of the components increased the preference of SBW, indicating a synergistic effect. However, SBW responded to 1,4-dimethoxybenzene, a major component of volatiles from $F$. viridis, previously found to synergize the attractiveness of the SBW aggregation pheromone in field studies.
\end{abstract}

Keywords Anthonomus rubi $\cdot$ Fragaria x ananassa $\cdot$ Fragaria vesca $\cdot$ Floral odors $\cdot$ Semiochemicals $\cdot$ Pest control

\section{Introduction}

The strawberry blossom weevil (SBW), Anthonomus rubi Herbst, (Coleoptera, Curculionidae) is an oligophagous species that feeds and reproduces on rosaceous plants (Popov

Raimondas Mozūraitis

raimondas.mozuraitis@su.se

1 Department of Zoology, Stockholm University, Stockholm, Sweden

2 Natural Resources Institute, University of Greenwich, Chatham Maritime, Kent ME4 4TB, UK

3 NIBIO, Norwegian Institute of Bioeconomy Research, NO-1431 Ås, Norway

4 Latvian Plant Protection Research Centre, Riga LV-1039, Latvia

5 Department of Plant and Environmental Sciences, University of Copenhagen, 1871 Frederiksberg C, Denmark
1996). Among its hosts are strawberry, Fragaria spp., raspberry, Rubus idaeus L., blackberry, Rubus spp. and rose, Rosa spp. (Hill 1987; Popov 1996). Early in spring, adults move to strawberry and raspberry from overwintering shelters, both inside the cropping area and from perimeter wild host plants

6 Agroscope, Research Center Conthey, 1964 Conthey, Switzerland

7 NIAB EMR, East Malling, Kent ME19 6BJ, UK

8 Norwegian Centre for Organic Agriculture, NO-6630 Tingvoll, Norway

9 Department of Chemistry, School of Engineering Science in Chemistry, Biotechnology and Health, KTH, Royal Institute of Technology, 10044 Stockholm, Sweden

10 Department of Chemical Engineering, Mid Sweden University, 85170 Sundsvall, Sweden 
(Alford 1984). There, they feed on foliage, flower buds and open flowers. The female weevil usually oviposits a single egg in an unopened bud (Aasen et al. 2004; Jary 1931; Leska 1965) before severing the bud petiole, either partially or completely, preventing further development of the bud. The oviposition period lasts 1-2 months, during which more than 150 buds can be destroyed per female (Easterbrook et al. 2003). The larva develops and pupates inside the withered bud and emerges in late summer. After emergence, the young adult feeds on foliage for a few weeks before moving to an overwintering site (Hill 1987).

The weevil is a serious pest of cultivated strawberry (Fragaria $x$ ananassa) throughout Europe (Cross et al. 2001), causing bud damage to $5-90 \%$ of the crop (Aasen and Trandem 2006; Cross et al. 2001; Labanowska 2004; Leska 1965; Kovanci et al. 2005; Krauß et al. 2014; Popov 1995; Svensson 2002). Resistance to pyrethroid insecticides makes effective control of SBW challenging (Aasen and Trandem 2006).

For many insects, pheromones are key cues in mate finding (Yew and Chung 2015), and can play an important role in integrated pest control programs (Suckling et al. 2014). The male-produced aggregation pheromone of SBW was identified as a blend of grandlure I, grandlure II and lavandulol in a 1:4:1 ratio by Innocenzi et al. (2001). This pheromone blend is attractive to both sexes and is used as a lure in commercial monitoring of SBW (Cross et al. 2006a, b). However, recent data suggested that, in order to control SBW populations, more effective lure formulations are needed (Baroffio et al. 2018). For a number of pests, the attractiveness of a pheromone can be enhanced by host plant volatiles (Reddy and Guerrero 2004). This has been demonstrated for other weevils of the genus Anthonomus (Dickens 1989; MunizMerino et al. 2014). Furthermore, it has been shown that combining a floral volatile, 1,4-dimethoxybenzene, with the aggregation pheromone of $A$. rubi, gives improved trap catches (Wibe et al. 2014). This compound is now included in commercially available lures.

The objective of this study was to identify other hostplant compound(s) that might be combined with the SBW aggregation pheromone to improve attraction of SBW. We aimed: (i) to determine whether SBW is able to discriminate between volatiles from flowering versus nonflowering strawberry plants of two species, Fragaria $x$ ananassa and F. vesca; (ii) to determine whether SBW prefers volatiles of flowering $F$. $x$ ananassa over those of flowering $F$. vesca; (iii) to identify components of the volatile floral blends of $F$. $x$ ananassa and $F$. vesca; and (iv) to determine whether selected components of these floral volatiles elicit behavioral responses by SBW in a laboratory bioassay when tested individually or in blends.

\section{Methods and Materials}

\section{Insects and Plants}

Adult SBW were collected from strawberry fields in SE Norway (N59.66, E10.69) in mid-May and transported to the laboratory at the Royal Institute of Technology, Stockholm. Both sexes were kept together on potted plants of non-flowering Fragaria x ananassa Duchesne (Rosales: Rosaceae), variety Sonata, enclosed in $400 \mathrm{~cm}^{3}$ plastic cups covered with nylon mesh. A moistened piece of cotton at the bottom of the cup served as a water source. The day before experiments, weevils were sexed and kept individually in plastic cups without plants. Sex was determined by the presence of a thorn on each intermediary coxa of male weevils (Innocenzi et al. 2002).

Fragaria $x$ ananassa plants of varieties Sonata, Beltran and Korona were obtained from the Plantagen Sweden stores. Wild strawberry, Fragaria vesca L. (Rosales: Rosaceae) plants were obtained from the strawberry genotype collection held at the Ecology Department, Swedish Agricultural University, Uppsala, Sweden. Location of the nine genotypes (I-IX) was the following: I - N59 59.287 , E17 25.578 ; II $\mathrm{N} 59^{\circ} 54.932, \mathrm{E} 17^{\circ} 08.646$; III - N59 ${ }^{\circ} 54.632$, E17 22.775 ; IV $-\mathrm{N} 59^{\circ} 53.858, \mathrm{E} 17^{\circ} 29.500 ; \mathrm{V}-\mathrm{N} 59^{\circ} 45.729, \mathrm{E} 17^{\circ} 20.524 ; \mathrm{VI}$

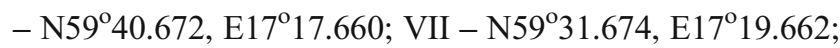
VIII - N59 ${ }^{\circ} 21.411$, E $18^{\circ} 17.118$; IX - N59 21.412 , E18 ${ }^{\circ} 17.118$. The plants were kept under laboratory conditions: $16: 8 \mathrm{~h} \mathrm{~L}: \mathrm{D}$ photoperiod and $\sim 18{ }^{\circ} \mathrm{C}$. A $1000 \mathrm{~W}$ daylight lamp (type DRF, for use in greenhouses) was used as the light source.

\section{Chemicals}

Benzaldehyde ( $>98 \%$ chemical purity), 4 methoxybenzaldehyde ( $p$-anisaldehyde; $>98 \%$ chemical purity), methyl salicylate (>98\% chemical purity) and benzyl alcohol (> 99\% chemical purity) were purchased from Alfa Aesar (Ward Hill, Massachusetts, USA). ( \pm )-Limonene (> $98 \%$ chemical purity), decanal (>98\% chemical purity), 1,4dimethoxybenzene ( $>99 \%$ chemical purity) and pentadecane (> 99\% chemical purity) were obtained from Sigma-Aldrich AB (Stockholm, Sweden), while $\alpha$-muurolene (95\% chemical purity) and analytical standards in Table 1 were available from the Ecological Chemistry group (Stockholm, Sweden). Diethyl ether (redistilled, 99.9\%) and cyclohexane (99.9\%) were purchased from Carlo Erba Reagents (Val de Reuil, France).

\section{Sampling and Analysis of Floral Volatiles}

We used solid-phase microextraction (SPME; Rout et al. 2012) to sample volatiles of three varieties of $F$. $x$ ananassa 
Table 1 Composition of odor blends from flowers of Fragaria ananasa cultivars Sonata, Beltran and Corona and $F$. vesca collected by solid phase microextraction, and previously reported olfactory activity of Anthonomus rubi to the compounds

\begin{tabular}{|c|c|c|c|c|c|c|c|c|c|}
\hline \multirow[b]{2}{*}{ No. } & \multirow[b]{2}{*}{ Of Compound } & \multirow[b]{2}{*}{$\mathrm{GR}^{\mathrm{a}}$} & \multirow[b]{2}{*}{$\mathrm{RI}^{\mathrm{b}}$} & \multirow[b]{2}{*}{$\mathrm{ID}^{\mathrm{c}}$} & \multicolumn{4}{|c|}{ Mean TIC count/g dry weight $/ \mathrm{h} \pm \mathrm{SE}(\times 10 \text { million })^{\mathrm{e}}$} & \multirow[b]{2}{*}{$\mathrm{OA}^{\mathrm{f}}$} \\
\hline & & & & & F. $a$. Sonata & F. a. Beltran & F. a. Corona & F. vesca & \\
\hline 1 & $\alpha$-Pinene & MT & 1017 & $\mathrm{RC}$ & $1 \pm 1 b^{g}$ & $3 \pm 1 b$ & 0 & $99 \pm 19 a$ & $t$ \\
\hline 2 & $\beta$-Pinene & MT & 1105 & $\mathrm{RC}$ & 0 & $\operatorname{tr}$ & 0 & $34 \pm 23$ & $t$ \\
\hline 3 & 3-Carene & MT & 1151 & $\mathrm{RC}$ & $1 \pm 1 \mathrm{~b}$ & $2 \pm 1 b$ & 0 & $18 \pm 7 \mathrm{a}$ & $t$ \\
\hline 4 & Limonene & MT & 1196 & $\mathrm{RC}$ & $19 \pm 6 b$ & $19 \pm 3 b$ & $33 \pm 8 b$ & $159 \pm 27 \mathrm{a}$ & $\S$ \\
\hline 5 & $\beta$-Phellandrene & MT & 1207 & $\mathrm{~L}, \mathrm{RI}$ & $\operatorname{tr}$ & $\operatorname{tr}$ & $2 \pm 2 \mathrm{a}$ & $9 \pm 4 \mathrm{a}$ & $\S$ \\
\hline 6 & $(Z)$ - $\beta$-Ocimene & MT & 1239 & $\mathrm{RC}$ & 0 & 0 & 0 & $\operatorname{tr}$ & $\S$ \\
\hline 7 & $(E)$ - $\beta$-Ocimene & MT & 1249 & $\mathrm{RC}$ & 0 & $9 \pm 9 \mathrm{a}$ & 0 & $24 \pm 14 \mathrm{a}$ & $\S$ \\
\hline 8 & $p$-Cymene & ARMT & 1260 & $\mathrm{RC}$ & $\operatorname{tr}$ & $\operatorname{tr}$ & $\operatorname{tr}$ & $8 \pm 5 \mathrm{a}$ & \\
\hline 9 & Hexyl acetate & $\mathrm{E}$ & 1269 & $\mathrm{RC}$ & $\operatorname{tr}$ & $2 \pm 1 b$ & $1 \pm 1 \mathrm{~b}$ & $10 \pm 3 \mathrm{a}$ & $t$ \\
\hline 10 & 1-Ethyl-2-methyl-benzene & $\mathrm{AR}$ & 1271 & $\mathrm{RC}$ & $\operatorname{tr}$ & $2 \pm 1 b$ & 0 & $25 \pm 5 \mathrm{a}$ & \\
\hline 11 & Octanal & $\mathrm{AL}$ & 1283 & $\mathrm{RC}$ & $9 \pm 1 \mathrm{c}$ & $18 \pm 4 \mathrm{bc}$ & $38 \pm 17 b$ & $108 \pm 34 \mathrm{a}$ & \\
\hline 12 & (Z)-3-Hexen-1-yl acetate & $\mathrm{E}$ & 1312 & $\mathrm{RC}$ & $43 \pm 30 \mathrm{ab}$ & $12 \pm 4 b$ & $53 \pm 15 \mathrm{a}$ & $80 \pm 12 \mathrm{a}$ & $t$ \\
\hline 13 & Methoxybenzene & $\mathrm{AR}$ & 1330 & $\mathrm{RC}$ & $10 \pm 4 \mathrm{ab}$ & $2 \pm 1 b$ & $11 \pm 3 \mathrm{a}$ & 0 & \\
\hline 14 & 6-Methyl-5-hepten-2-one & $\mathrm{K}$ & 1331 & $\mathrm{RC}$ & $5 \pm 1 \mathrm{c}$ & $12 \pm 3 b$ & $31 \pm 12 b$ & $86 \pm 11 \mathrm{a}$ & \\
\hline 15 & 1-Hexanol & $\mathrm{OH}$ & 1354 & $\mathrm{RC}$ & $7 \pm 3 \mathrm{ab}$ & $1 \pm 1 \mathrm{~b}$ & $14 \pm 10 \mathrm{ab}$ & $46 \pm 26 \mathrm{a}$ & $t$ \\
\hline 16 & methoxymethyl-Benzene & $\mathrm{AR}$ & 1379 & $\mathrm{RC}$ & $26 \pm 19 \mathrm{a}$ & $2 \pm 1 \mathrm{a}$ & 0 & 0 & \\
\hline 17 & (Z)-3-Hexen-1-ol & $\mathrm{OH}$ & 1380 & $\mathrm{RC}$ & $\operatorname{tr}$ & $1 \pm 1 \mathrm{~b}$ & $10 \pm 6 \mathrm{a}$ & $27 \pm 7 \mathrm{a}$ & $t$ \\
\hline 18 & Nonanal & $\mathrm{AL}$ & 1388 & $\mathrm{RC}$ & $42 \pm 5 c$ & $80 \pm 10 b$ & $212 \pm 39 a$ & $428 \pm 80 \mathrm{a}$ & \\
\hline 19 & Copaene & ST & 1483 & $\mathrm{RC}$ & 0 & 0 & 0 & $22 \pm 14$ & \\
\hline 20 & Decanal & $\mathrm{AL}$ & 1493 & $\mathrm{RC}$ & $64 \pm 10 b$ & $171 \pm 32 \mathrm{ab}$ & $310 \pm 50 \mathrm{a}$ & $525 \pm 134 \mathrm{a}$ & \\
\hline 21 & Benzaldehyde & $\mathrm{AR}$ & 1501 & $\mathrm{RC}$ & $78 \pm 4 \mathrm{ab}$ & $141 \pm 55 \mathrm{a}$ & $40 \pm 15 b$ & $64 \pm 10 \mathrm{ab}$ & \\
\hline 22 & Linalool & OMT & 1534 & $\mathrm{RC}$ & $\operatorname{tr}$ & 0 & 0 & 0 & $\ddagger$ \\
\hline 23 & $\beta$-Caryophyllene & $\mathrm{ST}$ & 1587 & $\mathrm{RC}$ & 0 & 0 & 0 & $25 \pm 18$ & $\S$ \\
\hline 24 & Methyl benzoate & AR & 1602 & $\mathrm{RC}$ & $13 \pm 2 \mathrm{a}$ & $9 \pm 5 \mathrm{a}$ & $8 \pm 1 \mathrm{a}$ & $12 \pm 6 \mathrm{a}$ & $\S$ \\
\hline 25 & 3,6,6-Trimethyl-2-norpinanone & OMT & 1618 & $\mathrm{~L}, \mathrm{RI}$ & 0 & 0 & 0 & $11 \pm 6$ & \\
\hline 26 & Acetophenone & $\mathrm{AR}$ & 1630 & $\mathrm{RC}$ & $\operatorname{tr}$ & $3 \pm 1 \mathrm{a}$ & $1 \pm 1 \mathrm{a}$ & $13 \pm 13 \mathrm{a}$ & \\
\hline 27 & 1-Ethenyl-4-methoxy-benzene & AR & 1661 & $\mathrm{RC}$ & $3 \pm 2 b$ & $26 \pm 8 \mathrm{a}$ & 0 & 0 & \\
\hline 28 & 3-Ethyl-benzaldehyde & $\mathrm{AR}$ & 1690 & $\mathrm{RC}$ & $8 \pm 3 b$ & $5 \pm 2 b$ & $6 \pm 2 b$ & $24 \pm 5 \mathrm{a}$ & \\
\hline 29 & Germacrene D & ST & 1696 & $\mathrm{RC}$ & 0 & 0 & 0 & $2 \pm 1$ & $\S$ \\
\hline 30 & $\alpha$-Muurolene & ST & 1716 & $\mathrm{RC}$ & $11 \pm 2 b$ & $10 \pm 5 b$ & $14 \pm 6 b$ & $604 \pm 104 \mathrm{a}$ & \\
\hline 31 & 4-Ethyl-benzaldehyde & $\mathrm{AR}$ & 1718 & $\mathrm{RC}$ & $6 \pm 2 b$ & $10 \pm 3 \mathrm{ab}$ & $6 \pm 2 b$ & $20 \pm 5 \mathrm{a}$ & \\
\hline 32 & $(E, E)$ - $\alpha$-Farnesene & ST & 1743 & $\mathrm{RC}$ & 0 & $2 \pm 2 b$ & 0 & $128 \pm 34 \mathrm{a}$ & \\
\hline 33 & Unidentified 1 (sesquiterpene) & $\mathrm{ST}$ & 1746 & $\mathrm{~L}, \mathrm{RI}$ & $\operatorname{tr}$ & $2 \pm 2 \mathrm{a}$ & 0 & $4 \pm 3 \mathrm{a}$ & \\
\hline 34 & Methyl salicylate & AR & 1754 & $\mathrm{RC}$ & $96 \pm 18 b$ & $59 \pm 27 b$ & $35 \pm 18 b$ & $268 \pm 32 \mathrm{a}$ & $\S$ \\
\hline 35 & TMTT $^{\mathrm{d}}$ & HT & 1801 & $\mathrm{RC}$ & 0 & 0 & 0 & $15 \pm 8$ & \\
\hline 36 & Dihydro $\alpha$-ionone & $\mathrm{TK}$ & 1802 & $\mathrm{RC}$ & $\operatorname{tr}$ & $12 \pm 5$ & 0 & 0 & \\
\hline 37 & Unidentified 2 (sesquiterpene) & ST & 1847 & L, RI & 0 & $4 \pm 2 \mathrm{a}$ & $12 \pm 6 \mathrm{a}$ & 0 & \\
\hline 38 & Benzyl alcohol CAS\#: & AR & 1859 & $\mathrm{RC}$ & $310 \pm 32 \mathrm{a}$ & $136 \pm 63 b$ & $99 \pm 24 b$ & $312 \pm 41 \mathrm{a}$ & \\
\hline 39 & Benzyl isovalerate & AR & 1876 & $\mathrm{RC}$ & $4 \pm 1 \mathrm{ab}$ & $22 \pm 11 \mathrm{a}$ & $5 \pm 3 \mathrm{ab}$ & 0 & \\
\hline 40 & 2-Phenylethanol & $\mathrm{AR}$ & 1894 & $\mathrm{RC}$ & $17 \pm 2 \mathrm{ab}$ & $8 \pm 3 b$ & $88 \pm 47$ a & $106 \pm 48 \mathrm{a}$ & \\
\hline 41 & 1,4-Butanediol & $\mathrm{OH}$ & 1912 & $\mathrm{~L}, \mathrm{RI}$ & 0 & 0 & 0 & $20 \pm 11$ & \\
\hline 42 & 1,2-Benzisothiazole & $\mathrm{O}$ & 1931 & $\mathrm{~L}, \mathrm{RI}$ & $26 \pm 14 \mathrm{a}$ & $6 \pm 2 \mathrm{a}$ & $8 \pm 1 \mathrm{a}$ & $14 \pm 5 \mathrm{a}$ & \\
\hline 43 & 4-Metoxy-benzaldehyde & ARE & 1998 & $\mathrm{RC}$ & $1997 \pm 541 \mathrm{a}$ & $1144 \pm 433 \mathrm{a}$ & $1532 \pm 536 \mathrm{a}$ & 0 & \\
\hline 44 & Methyl 2-methoxy-benzoate & ARE & 2049 & $\mathrm{RC}$ & $12 \pm 7 \mathrm{a}$ & $8 \pm 4 \mathrm{a}$ & $10 \pm 1 \mathrm{a}$ & 0 & \\
\hline 45 & Benzyl 2-methyl-( $E$ or $Z$ )-2-butenoate & ARE & 2092 & $\mathrm{~L}, \mathrm{RI}$ & $30 \pm 5 \mathrm{a}$ & $70 \pm 46 \mathrm{a}$ & $23 \pm 13 \mathrm{a}$ & 0 & \\
\hline 46 & Hexahydrofarnesyl acetone & TK & 2120 & $\mathrm{RC}$ & $6 \pm 2 b$ & $19 \pm 6 \mathrm{ab}$ & $14 \pm 4 \mathrm{ab}$ & $35 \pm 7 \mathrm{a}$ & \\
\hline
\end{tabular}


Table 1 (continued)

Mean TIC count/g dry weight $/ \mathrm{h} \pm \mathrm{SE}(\times 10 \text { million })^{\mathrm{e}}$

\begin{tabular}{|c|c|c|c|c|c|c|c|c|c|}
\hline No. & Of Compound & $\mathrm{GR}^{\mathrm{a}}$ & $\mathrm{RI}^{\mathrm{b}}$ & $\mathrm{ID}^{\mathrm{c}}$ & F. a. Sonata & F. a. Beltran & F. a. Corona & F. vesca & $\mathrm{OA}^{\mathrm{f}}$ \\
\hline 47 & 2-Phenoxyethanol & $\mathrm{AR}$ & 2122 & $\mathrm{RC}$ & $3 \pm 2 b$ & $\operatorname{tr}$ & $4 \pm 1 \mathrm{a}$ & $\operatorname{tr}$ & \\
\hline 48 & Unidentified 3 & & 2133 & & $28 \pm 3 \mathrm{a}$ & $7 \pm 3 b$ & $26 \pm 8 \mathrm{a}$ & 0 & \\
\hline 49 & Unidentified 4 & $\mathrm{E}$ & 2240 & & $15 \pm 5 \mathrm{a}$ & $8 \pm 6 \mathrm{a}$ & $25 \pm 9 \mathrm{a}$ & $59 \pm 20 \mathrm{a}$ & \\
\hline 50 & 4-Methoxybenzyl ethanol & $\mathrm{AR}$ & 2257 & $\mathrm{RC}$ & $60 \pm 14 \mathrm{a}$ & $24 \pm 6 b$ & $34 \pm 9 \mathrm{ab}$ & 0 & \\
\hline 51 & 3,4-Dimethoxybenzaldehyde & $\mathrm{AR}$ & 2365 & $\mathrm{RC}$ & $7 \pm 5 \mathrm{a}$ & $3 \pm 1 \mathrm{~b}$ & $\operatorname{tr}$ & 0 & \\
\hline 52 & Unidentified 5 & & 2376 & & $16 \pm 6 \mathrm{a}$ & $7 \pm 5 \mathrm{a}$ & $19 \pm 6 \mathrm{a}$ & $52 \pm 13$ a & \\
\hline 53 & Unidentified 6 & & 2480 & & $19 \pm 7 \mathrm{a}$ & $11 \pm 7 \mathrm{a}$ & $32 \pm 5 \mathrm{a}$ & $60 \pm 24 \mathrm{a}$ & \\
\hline 54 & Unidentified 7 & & 2487 & & $49 \pm 18 \mathrm{a}$ & $9 \pm 6 \mathrm{a}$ & $6 \pm 2 \mathrm{a}$ & 0 & \\
\hline 55 & Benzyl benzoate & $\mathrm{AR}$ & 2629 & $\mathrm{RC}$ & $46 \pm 8 \mathrm{a}$ & $136 \pm 80 \mathrm{a}$ & $19 \pm 10 \mathrm{a}$ & 0 & \\
\hline 56 & Unidentified 8 & & 2690 & & $11 \pm 7 \mathrm{a}$ & $3 \pm 3 \mathrm{a}$ & $12 \pm 7 \mathrm{a}$ & 0 & \\
\hline 57 & Unidentified 9 & & 2851 & & $\operatorname{tr}$ & $\operatorname{tr}$ & 0 & $44 \pm 14$ & \\
\hline
\end{tabular}

${ }^{\mathrm{a}} \mathrm{GR}$ = group of chemical compound (MT monoterpene; ARMT aromatic monoterpene; E ester; AR aromatic; AL aldehyde; K ketone; OH alcohol; OMT oxygenated monoterpene; ST sesquiterpene; HT homoterpene; TK terpene ketone; ARE aromatic ester; O other compound)

${ }^{\mathrm{b}} \mathrm{RI}=$ retention index (DB-Wax fused silica capillary column $30 \mathrm{~m} \times 0.25 \mathrm{~mm}$ i.d., $0.25 \mu \mathrm{m}$ film thickness)

${ }^{\mathrm{c}} \mathrm{ID}=$ identification source; $\mathrm{RC}=$ reference compound; $\mathrm{RI}=$ retention index; $\mathrm{L}=\mathrm{NIST}$ and MassFinder3 libraries

${ }^{\mathrm{d}}$ TMTT $=(3 \mathrm{E}, 7 \mathrm{E})-4,8,12$ - Trimethyltrideca-1,3,5,7,11-tetraene

${ }^{\mathrm{e}} \mathrm{TIC}=$ total ion chromatogram; $\mathrm{SE}=$ standard error of mean; $\operatorname{tr}=\operatorname{trace} ; \mathrm{F} . \mathrm{a}$. Sonata $(N=3)$, F. a. Beltran $(\mathrm{N}=4)$, F. a. Corona $(\mathrm{N}=4)$, and F. vesca $(\mathrm{N}=$ 9)

${ }^{\mathrm{f}} \mathrm{OA}=$ olfactory activity reported in A. rubi; $\S$ Bichão et al. 2005a, \$ Bichão et al. 2005b

${ }^{\mathrm{g}}$ The means indicated by the same letter in each row are not different (nonparametric Conover-Iman test, $P<0.05$ )

and flowers of different genotypes of $F$. vesca using the same fiber type, headspace volume, and temperature during sampling. An internal standard was used to check for saturation of fibers. This is a sensitive technique and provided quantitative data for statistical comparisons among varieties and species. Even so, comparison of quantities of different compounds in the same sample is not possible without use of labelled standards, because of different affinities of the fiber for compounds and different vapor pressures of compounds (SPME guidelines 2020). Thus, dynamic headspace sampling with an internal standard was also used for more reliable quantification of compounds and release rates.

SPME sampling was carried out with polydimethylsiloxane-divinylbenzene-coated fibers (65 $\mu \mathrm{m}$; Supelco, Sigma-Aldrich group, PA, USA) (Vas and Vekey 2004), desorbed at $250{ }^{\circ} \mathrm{C}$ for $2 \mathrm{~min}$ in a gas chromatograph (GC) injector prior to sampling. A single, ready-to-flower bud from a potted strawberry plant was placed in a glass chamber $\left(30 \mathrm{~cm}^{3}\right)$ through an opening at the bottom, along with a filter paper $\left(1 \mathrm{~cm}^{2}\right)$ treated with $100 \mathrm{ng}$ of pentadecane per $10 \mu \mathrm{l}$ of cyclohexane as internal standard. The opening was carefully sealed with aluminum foil. After the bud had opened, the SPME fiber was introduced close to the flower through a second opening in the chamber. Sampling of volatiles was carried out from 08.00 until $18.00 \mathrm{~h}$ covering the main period of emission (Ceuppens et al. 2015). After collection, the fiber was removed and desorbed directly in the injector of the gas chromatograph/mass spectrometer (GC/MS). Volatiles were collected from individual flowers of $F$. ananassa variety Sonata $(N=3), F$. ananassa variety Beltran $(N=4)$, $F$. ananassa variety Corona $(N=4)$, and $F$. vesca $(N=9)$.

Dynamic headspace sampling (Millar and Haynes 1998) was carried out on individual flowers of $F$. ananassa variety Sonata $(N=3)$ and $F$. vesca $(N=3)$. A single, ready-to-flower bud was placed in the type of glass jar used for SPME sampling. Charcoal-purified and humidified air $\left(50 \mathrm{ml} . \mathrm{min}^{-1}\right)$ was supplied by a diaphragm vacuum pump (NMP 830 KNDCB; KNF Neuberger Inc., Freiburg, Germany), and pulled through a glass collection tube containing Tenax TA adsorbent (50 mg; 60/80 mesh; Sigma-Aldrich AB, Sweden) by a second pump. Volatiles were collected from $08.00-18.00 \mathrm{~h}$ as above. After sampling, traps were extracted with $250 \mu \mathrm{l}$ of redistilled diethyl ether, and $20 \mathrm{ng}$ of pentadecane in cyclohexane was added as internal standard. Samples were concentrated under a gentle flow of nitrogen and analyzed on the same day as collected.

After sampling, flowers were detached from the peduncle, placed in a glass beaker and kept in a thermostat at $60{ }^{\circ} \mathrm{C}$ for $72 \mathrm{~h}$ for determination of dry weight. For both sampling 
techniques, volatiles were also collected from empty glass chambers.

Samples were analyzed using a Varian $3400 \mathrm{GC}$ coupled to a Finnigan SSQ 7000 MS (Thermo-Fisher Scientific, USA). A DB-Wax fused silica capillary column (30 m length, $0.25 \mathrm{~mm}$ id, $0.25 \mu \mathrm{m}$ film thickness; Supelco-Sigma-Aldrich group, USA) was used. The column oven was programmed from $40{ }^{\circ} \mathrm{C}$ for $3 \mathrm{~min}$, then at $4{ }^{\circ} \mathrm{C} \cdot \mathrm{min}^{-1}$ to $200{ }^{\circ} \mathrm{C}$, then at $10{ }^{\circ} \mathrm{C} \cdot \mathrm{min}^{-1}$ to $230{ }^{\circ} \mathrm{C}$, and held for $9 \mathrm{~min}$. The split/splitless injector temperature was $225{ }^{\circ} \mathrm{C}$ and the splitless period lasted for $60 \mathrm{~s}$. Helium was used as carrier gas with an inlet pressure of $70 \mathrm{kPa}$. The transfer line temperature was $235^{\circ} \mathrm{C}$. Electron ionization mass spectra were determined at $70 \mathrm{eV}$ with an ion source at $150{ }^{\circ} \mathrm{C}$. Chromatographic profiles of volatiles were compared and compounds in large amounts, relative to those in blank samples, identified by comparison of mass spectral data and retention indices with synthetic standards (Table 2), along with data from NIST version 2.0 mass spectral search program (National Institute of Standards and Technology, USA). Relative amounts of compounds were determined as areas under chromatographic peaks. Absolute amounts of compounds trapped by aeration were quantified by applying standard calibration curves derived from pentadecane at $0.5 \mathrm{ng}, 1 \mathrm{ng}$, $10 \mathrm{ng}$ and $50 \mathrm{ng}$.

\section{Behavioral Tests}

Behavioral responses of SBW to natural and synthetic odors were tested in two-choice olfactometers. The test area was illuminated with a quartz metal halide lamp (HPI-T Plus $400 \mathrm{~W}$; Philips, Amsterdam, the Netherlands) placed $180 \mathrm{~cm}$ above the olfactometers. The olfactometers comprised three layers of acrylic plastic (each layer $0.5 \mathrm{~cm}$ thick) sandwiched together with an arena cut out in the middle layer and consisting of a central zone $(2 \times 2.5 \mathrm{~cm})$ with two tapered arm zones $(4 \mathrm{~cm}$ length from the air inlet to the central zone and $0.4 \mathrm{~cm}$ to $2.5 \mathrm{~cm}$ width at the inlet and the central zone, respectively) (Hambäck et al. 2003) (Fig. 5a). One vacuum diaphragm pump delivered stimuli in purified and humidified air to the arms of the olfactometer and another pump was connected via Teflon tubes to the top so as to withdraw air at ca. $3 \mathrm{ml} . \mathrm{sec}^{-1}$. Four olfactometer trials could be run simultaneously, testing an odorant of the same type. Before each trial, a weevil was allowed to acclimatize inside the olfactometer for $3 \mathrm{~min}$. During delivery of the stimulus, the weevil's position in the arena was noted at $30 \mathrm{~s}$ intervals for $15 \mathrm{~min}$, giving a total of 30 recordings for each individual weevil. The responsiveness of a SBW was assessed by calculating the percentage of records in each arm. Each weevil was only used once in an experiment, and weevils that were inactive in the central zone for more than $5 \mathrm{~min}$ during trials were excluded from the analysis. Between trials, the olfactometers were washed with water and a mild detergent.

In the first experiment, weevil preference to the olfactometer arms without olfactory cues was tested to confirm lack of bias in the olfactometer. In the second experiment, weevil responses to odors from flowering versus non-flowering strawberry plants were evaluated. For the non-flowering plants, buds or flowers were removed $2 \mathrm{~d}$ prior to the experiment. A single potted flowering and non-flowering $F . x$ ananassa plant were placed separately in a polyester cooking bag $(25 \times 40 \mathrm{~cm}$; Toppits, Minden, Germany), while $4-5$ potted flowering and non-flowering $F$. vesca plants (collected at $\left.\mathrm{N} 59^{\circ} 21.412, \mathrm{E} 18^{\circ} 17.118\right)$ of total leaf area approximately equal (estimated by visual evaluation) to that of the $F . x$ ananassa plant were placed together in another polyester cooking bag. One $F . x a$. var. Sonata flower corresponded to four $F$. vesca flowers, based on dry weight. The pots were covered with aluminum foil in order to minimize soil volatiles in the headspace. Purified and humidified air was delivered at a ca. $12 \mathrm{ml} . \mathrm{sec}^{-1}$ from the bottom of the bag, and volatiles were collected at the top of the bag.

In the third experiment we tested preference for flowering $F$. vesca versus flowering $F . x a$. var. Sonata plants, using five wild strawberry plants with eleven flowers and one garden strawberry plant with three flowers, respectively.

In the fourth experiment, the responses of SBW to synthetic chemicals added to non-flowering plants were tested against plants alone. Compounds were dissolved in cyclohexane and $10 \mu \mathrm{l}$ of solution applied to $2 \mathrm{~cm}^{2}$ of filter paper in a glass vial $\left(10 \mathrm{~cm}^{3}\right)$ positioned close to the plant. Single compounds were tested at a dose of $100 \mathrm{ng}$. Two six-component blends of synthetic compounds were made to represent floral bouquets of $F$. $x$ ananassa var. Sonata (FAS) and $F$. vesca (FV), respectively. The FAS blend comprised 4methoxybenzaldehyde, benzaldehyde, benzyl alcohol, methyl salicylate, limonene and decanal at loadings of 200, 15, 51, 20, 9 and $40 \mathrm{ng}$, respectively. The FV blend comprised $\alpha$ muurolene, benzaldehyde, benzyl alcohol, methyl salicylate, limonene and decanal at loadings of 30, 25, 45, 60, 70 and $80 \mathrm{ng}$, respectively. The loading ratios and amounts of synthetic odorants were selected to emit profiles similar to those of strawberry flowers. Five components in these two synthetic blends were common, consistent with the observation that SBW showed no preference for flowering plants of either species. All five compounds were previously shown to elicit electrophysiological responses from the antennae of SBW by Bichão et al. (2005a). Furthermore, these compounds represent different classes of floral volatiles and would be economically feasible for practical control use. In addition, the FAS blend included 4-methoxybenzaldehyde, the major component in floral volatiles from cultivated strawberry, while the 
Table 2 Composition of volatiles from flowers of Fragaria ananasa cultivar Sonata and $F$. vesca flowers collected by dynamic headspace technique

\begin{tabular}{|c|c|c|c|c|c|c|}
\hline \multirow[b]{2}{*}{ No } & \multirow[b]{2}{*}{ Compound } & \multirow[b]{2}{*}{$\mathrm{GR}^{\mathrm{a}}$} & \multirow[b]{2}{*}{$\mathrm{RI}^{\mathrm{b}}$} & \multirow[b]{2}{*}{$\mathrm{ID}^{\mathrm{c}}$} & \multicolumn{2}{|c|}{ Mean rate \pm SE (ng/g dry weight $/ \mathrm{h})^{\mathrm{e}}$} \\
\hline & & & & & F. a. Sonata & F. vesca \\
\hline \multirow[t]{2}{*}{1} & $\alpha$-Pinene & MT & 1017 & $\mathrm{RC}$ & $0.5 \pm 0.29$ & $4.4 \pm 3.07 \mathrm{def}^{\mathrm{f}}$ \\
\hline & Hexanal & $\mathrm{AL}$ & 1076 & $\mathrm{RC}$ & $0.3 \pm 0.15$ & 0 \\
\hline 2 & $\beta$-Pinene & MT & 1105 & $\mathrm{RC}$ & $0.2 \pm 0.06$ & 0 \\
\hline \multirow[t]{2}{*}{3} & 3-Carene & MT & 1151 & $\mathrm{RC}$ & $0.3 \pm 0.12$ & 0 \\
\hline & Heptanal & $\mathrm{AL}$ & 1180 & $\mathrm{RC}$ & $0.3 \pm 0.02$ & $2.4 \pm 1.8 \mathrm{f}$ \\
\hline \multirow[t]{2}{*}{4} & Limonene & MT & 1196 & $\mathrm{RC}$ & $1.6 \pm 0.52 \mathrm{~d}$ & $11.9 \pm 1.46 \mathrm{bcd}$ \\
\hline & Propylbenzene & $\mathrm{AR}$ & 1198 & $\mathrm{RC}$ & $0.3 \pm 0.20$ & 0 \\
\hline \multirow[t]{2}{*}{5} & $\beta$-Phellandrene & MT & 1207 & $\mathrm{~L}, \mathrm{RI}$ & $0.1 \pm 0.04$ & 0 \\
\hline & (E)-2-Hexenal & $\mathrm{AL}$ & 1208 & $\mathrm{RC}$ & $0.1 \pm 0.05$ & $3.5 \pm 2.44 \mathrm{ef}$ \\
\hline 6 & $(Z)$ - $\beta$-Ocimene & MT & 1239 & $\mathrm{RC}$ & $\operatorname{tr}$ & 0 \\
\hline 7 & $(E)$ - $\beta$-Ocimene & MT & 1249 & $\mathrm{RC}$ & $\operatorname{tr}$ & $3.0 \pm 1.2 \mathrm{ef}$ \\
\hline 8 & $p$-Cymene & ARMT & 1260 & $\mathrm{RC}$ & $\operatorname{tr}$ & 0 \\
\hline 10 & Hexyl acetate & $\mathrm{E}$ & 1269 & $\mathrm{RC}$ & $0.1 \pm 0.06$ & 0 \\
\hline 11 & Octanal & $\mathrm{AL}$ & 1284 & $\mathrm{RC}$ & $3.7 \pm 0.60 \mathrm{~cd}$ & $6.8 \pm 0.45 \mathrm{de}$ \\
\hline 12 & (Z)-3-Hexen-1-yl acetate & $\mathrm{E}$ & 1312 & $\mathrm{RC}$ & $2.1 \pm 1.07 \mathrm{~d}$ & $9.1 \pm 1.91 \mathrm{bcd}$ \\
\hline 13 & Methoxybenzene & $\mathrm{AR}$ & 1331 & $\mathrm{RC}$ & $0.7 \pm 0.55$ & 0 \\
\hline 14 & 6-Methyl-5-hepten-2-one & $\mathrm{K}$ & 1332 & $\mathrm{RC}$ & $9.7 \pm 2.16$ & $\operatorname{tr}$ \\
\hline 15 & 1-Hexanol & $\mathrm{OH}$ & 1355 & $\mathrm{RC}$ & $2.1 \pm 0.25$ & 0 \\
\hline 16 & Methoxymethyl-benzene & $\mathrm{AR}$ & 1380 & $\mathrm{RC}$ & $0.3 \pm 0.12$ & 0 \\
\hline 17 & (Z)-3-Hexen-1-ol & $\mathrm{OH}$ & 1381 & $\mathrm{RC}$ & $0.8 \pm 0.26$ & 0 \\
\hline 18 & Nonanal & $\mathrm{AL}$ & 1389 & $\mathrm{RC}$ & $13.0 \pm 1.63 b$ & $9.7 \pm 0.71 \mathrm{bcd}$ \\
\hline 19 & $\alpha$-Copaene & ST & 1484 & $\mathrm{RC}$ & $\operatorname{tr}$ & 0 \\
\hline 20 & Decanal & $\mathrm{AL}$ & 1493 & $\mathrm{RC}$ & $18.9 \pm 7.78 \mathrm{ab}$ & $8.9 \pm 1.76 \mathrm{bcd}$ \\
\hline 21 & Benzaldehyde & $\mathrm{AR}$ & 1501 & $\mathrm{RC}$ & $9.6 \pm 0.76 b$ & $14.5 \pm 2.58 \mathrm{ab}$ \\
\hline 22 & Linalool & OMT & 1534 & $\mathrm{RC}$ & $0.2 \pm 0.08$ & $7.3 \pm 1.71 \mathrm{cde}$ \\
\hline \multirow[t]{2}{*}{23} & $\beta$-Caryophyllene & ST & 1587 & $\mathrm{RC}$ & 0.0 & $2.5 \pm 0.64 f$ \\
\hline & Undecanal & $\mathrm{AL}$ & 1597 & $\mathrm{RC}$ & $1.5 \pm 0.4 \mathrm{~d}$ & 0 \\
\hline 24 & Methyl benzoate & $\mathrm{AR}$ & 1602 & $\mathrm{RC}$ & $2.1 \pm 0.41 \mathrm{~d}$ & 0 \\
\hline 26 & Acetophenone & $\mathrm{K}$ & 1630 & $\mathrm{RC}$ & $0.2 \pm 0.14$ & $8.2 \pm 2.21 \mathrm{bcd}$ \\
\hline 27 & 1-Ethenyl-4-methoxybenzene & $\mathrm{AR}$ & 1661 & $\mathrm{RC}$ & $1.0 \pm 0.11$ & 0 \\
\hline \multirow[t]{2}{*}{29} & Germacrene D & ST & 1696 & $\mathrm{RC}$ & $0.4 \pm 0.27$ & $1.4 \pm 0.73 \mathrm{f}$ \\
\hline & Unidentified 1 (sesquiterpene) & ST & 1715 & $\mathrm{RC}$ & $0.1 \pm 0.04$ & 0 \\
\hline 30 & $\alpha$-Muurolene & ST & 1716 & $\mathrm{RC}$ & $0.1 \pm 0.05$ & $18.5 \pm 1.79 \mathrm{a}$ \\
\hline 32 & $(E, E)$ - $\alpha$-Farnesene & ST & 1743 & $\mathrm{RC}$ & $1.2 \pm 0.26 \mathrm{~d}$ & 0 \\
\hline 34 & Methyl salicylate & $\mathrm{AR}$ & 1754 & $\mathrm{RC}$ & $2.6 \pm 0.41 \mathrm{c}$ & $9.0 \pm 1.47 \mathrm{bcd}$ \\
\hline \multirow[t]{2}{*}{35} & $\mathrm{TMTT}^{\mathrm{d}}$ & HT & 1801 & $\mathrm{RC}$ & $0.5 \pm 0.22$ & $4.1 \pm 0.86 \mathrm{ef}$ \\
\hline & Unidentified 2 (sesquiterpene) & OST & 1847 & $\mathrm{~L}, \mathrm{RI}$ & $11.9 \pm 7.55 \mathrm{abc}$ & 0 \\
\hline 38 & Benzyl alcohol & $\mathrm{AR}$ & 1859 & $\mathrm{RC}$ & $11.0 \pm 5.18 \mathrm{ab}$ & $10.8 \pm 2.35 b c$ \\
\hline 39 & Benzyl isovalerate & $\mathrm{AR}$ & 1875 & $\mathrm{RC}$ & $\operatorname{tr}$ & 0 \\
\hline 40 & 2-Phenylethanol & $\mathrm{AR}$ & 1893 & $\mathrm{RC}$ & $3.2 \pm 2.79 \mathrm{~cd}$ & 0 \\
\hline 42 & 1,2-Benzisothiazole & $\mathrm{O}$ & 1930 & $\mathrm{~L}, \mathrm{RI}$ & $\operatorname{tr}$ & 0 \\
\hline 43 & 4-Methoxybenzaldehyde & $\mathrm{AR}$ & 1997 & $\mathrm{RC}$ & $23.0 \pm 2.37 \mathrm{a}$ & 0 \\
\hline 44 & Methyl 2-methoxybenzoate & ARE & 2048 & $\mathrm{RC}$ & $\operatorname{tr}$ & 0 \\
\hline \multirow[t]{2}{*}{45} & Benzyl 2-methyl-( $E$ or $Z$ )-2-butenoate & ARE & 2091 & $\mathrm{~L}, \mathrm{RI}$ & $\operatorname{tr}$ & 0 \\
\hline & (Z)-3-Hexen-1-ol benzoate & $\mathrm{E}$ & 2103 & $\mathrm{RC}$ & $\operatorname{tr}$ & 0 \\
\hline \multirow[t]{2}{*}{46} & Hexahydrofarnesyl acetone & TK & 2119 & $\mathrm{RC}$ & $\operatorname{tr}$ & 0 \\
\hline & Unidentified 3 & & 2132 & & $0.6 \pm 0.45$ & 0 \\
\hline
\end{tabular}


Table 2 (continued)

\begin{tabular}{|c|c|c|c|c|c|c|}
\hline \multirow[b]{2}{*}{ No } & \multirow[b]{2}{*}{ Compound } & \multirow[b]{2}{*}{$\mathrm{GR}^{\mathrm{a}}$} & \multirow[b]{2}{*}{$\mathrm{RI}^{\mathrm{b}}$} & \multirow[b]{2}{*}{$\mathrm{ID}^{\mathrm{c}}$} & \multicolumn{2}{|c|}{ Mean rate \pm SE (ng/g dry weight $/ \mathrm{h})$} \\
\hline & & & & & F. a. Sonata & F. vesca \\
\hline & Unidentified 4 & & 2239 & & $0.1 \pm 0.4$ & 0 \\
\hline 50 & 4-Methoxybenzyl alcohol & $\mathrm{AR}$ & 2256 & $\mathrm{RC}$ & $\operatorname{tr}$ & 0 \\
\hline 55 & Benzyl benzoate & $\mathrm{AR}$ & 2629 & $\mathrm{RC}$ & $0.2 \pm 0.12$ & 0 \\
\hline
\end{tabular}

${ }^{\mathrm{a}} \mathrm{GR}=$ group of chemical compound $(\mathrm{MT}=$ monoterpene; $\mathrm{AL}=$ aldehyde; $\mathrm{AR}=$ aromatic; $\mathrm{ARMT}=$ aromatic monoterpene; $\mathrm{E}=$ ester; $\mathrm{HT}=$ homoterpene; $\mathrm{K}=$ ketone; $\mathrm{O}=$ other compound; $\mathrm{OH}=$ alcohol; $\mathrm{OMT}=$ oxygenated monoterpene; $\mathrm{ST}=$ sesquiterpene; $\mathrm{TK}=$ terpene ketone

${ }^{\mathrm{b}} \mathrm{RI}=$ retention index (DB-Wax fused silica capillary column $30 \mathrm{~m} \times 0.25 \mathrm{~mm}$ i.d., $0.25 \mu \mathrm{m}$ film thickness)

${ }^{\mathrm{c}} \mathrm{ID}=$ identification source; $\mathrm{RC}=$ reference compound; $\mathrm{RI}=$ retention index; $\mathrm{L}=\mathrm{NIST}$ and MassFinder3 libraries

${ }^{\mathrm{d}}$ TMTT $=(3 E, 7 E)-4,8,12$ - Trimethyltrideca-1,3,5,7,11-tetraene

${ }^{\mathrm{e}} \mathrm{SE}=$ standard error of mean; $\mathrm{tr}=\operatorname{trace} ; F$. $a$. Sonata $(\mathrm{N}=3)$ and $F$. vesca $(\mathrm{N}=3)$

${ }^{\mathrm{f}}$ The means indicated by the same letter in each column are not different (nonparametric Conover-Iman test, $\mathrm{P}<0.05$, calculated for the compounds with amount exceeding $1 \mathrm{ng}$ )

FV blend contained $\alpha$-muurolene, the major component in volatiles from wild strawberry.

In the fifth experiment, the responses of SBW to 4methoxybenzaldehyde added to non-flowering $F x$ ananassa var. Sonata plants at doses of $10 \mathrm{ng}, 100 \mathrm{ng}$ and $1000 \mathrm{ng}$ were investigated.

\section{Data Analysis}

To monitor saturation of SPME fibers, the amounts of pentadecane adsorbed were compared by Mann Whitney U test, using Statistica software version 6.0.

To compare amounts of floral volatiles between $F . x$ ananassa varieties and $F$. vesca, data were analyzed by Kruskal-Wallis a non-parametric test followed by a Conover-Iman test using $\mathrm{R}$ (version 4.0.2) and Rstudio (version 1.3.959).

To assess and visualize associations among odor blends of strawberry flowers sampled by SPME, a multidimensional scaling (MDS) analysis with a Bray-Curtis index was performed on absolute amounts, expressed as areas under chromatographic peaks, using R (version 4.0.2) and Rstudio (version 1.3.959), with the metaMDS function in the vegan package (version 2.5-6). The results were visualized using ggplot2 (version 3.3.2). Prior to analysis, the data were square root transformed. Amounts of volatiles were also used to show degree of similarity of odor bouquets between $F$. $x$ ananassa varieties and $F$. vesca by cluster analysis, based on Euclidian distance using Statistica software version 6.0.

The behavioral responses of SBW in two-choice olfactometer tests were analyzed by nonparametric Wilcoxon matchedpairs signed-ranks test using the Statistica software version 6.0 .

\section{Results}

\section{Chemical Composition and Variation of Strawberry Floral Odor Blends}

Using SPME, 46, 39 and 49 compounds were detected in floral volatiles from $F . x$ ananassa varieties Sonata, Beltran, and Korona, respectively. In the flower headspace of $F$. vesca, 41 compounds were detected (Table 1). Monitoring saturation of SPME fibers by adding 100 ng of pentadecane as internal standard to the samples revealed no differences in amount of pentadecane trapped on the fibers in blank samples (empty glass jars; median TIC count 17,934,247) versus $F$. vesca flowers (median TIC count 15,258,935) and versus flowers of F. $x$ ananassa variety Sonata (median TIC count $11,565,433$ ) (Mann Whitney U test, $N=5, P=0.222$ and $N=3, P=0.071$, respectively).

Using the dynamic headspace sampling technique, 49 compounds were detected in floral volatiles collected from $F$. $x$ ananassa variety Sonata and 18 compounds from $F$. vesca (Table 2). For both techniques, all samples were from single flowers. GC/MS analyses revealed that floral volatile blends of both species were dominated by aromatic compounds and terpenoids. From the flowers of $F . x$ ananassa, 4methoxybenzaldehyde ( $p$-anisaldehyde) was collected in the largest quantity, and from $F$. vesca, $\alpha$-muurolene (Fig. 1, Tables 1 and 2).

Multidimensional scaling (MDS) analysis, using data from SPME samplings, showed that odor blends released from $F$. $x$ ananass $a$ and $F$. vesca flowers were separated from each other (Fig. 2). The first MDS axis explained separation between specimens of $F$. x ananassa and $F$. vesca species. Twenty four compounds had significantly higher amounts per gram of dry flower weight released per hour for $F$. vesca than for $F$. $x$ 
Fig. 1 Total ion chromatograms from gas chromatography/mass spectrometry analyses of floral odors collected by solid phase microextraction headspace sampling of a single flower of Fragaria $x$ ananassa varieties Sonata, Beltran, Korona, and $F$. vesca. (DB-Wax fused silica capillary column; numbered chromatographic peaks are listed in Tables 1 and 2; IS pentadecane internal standard)

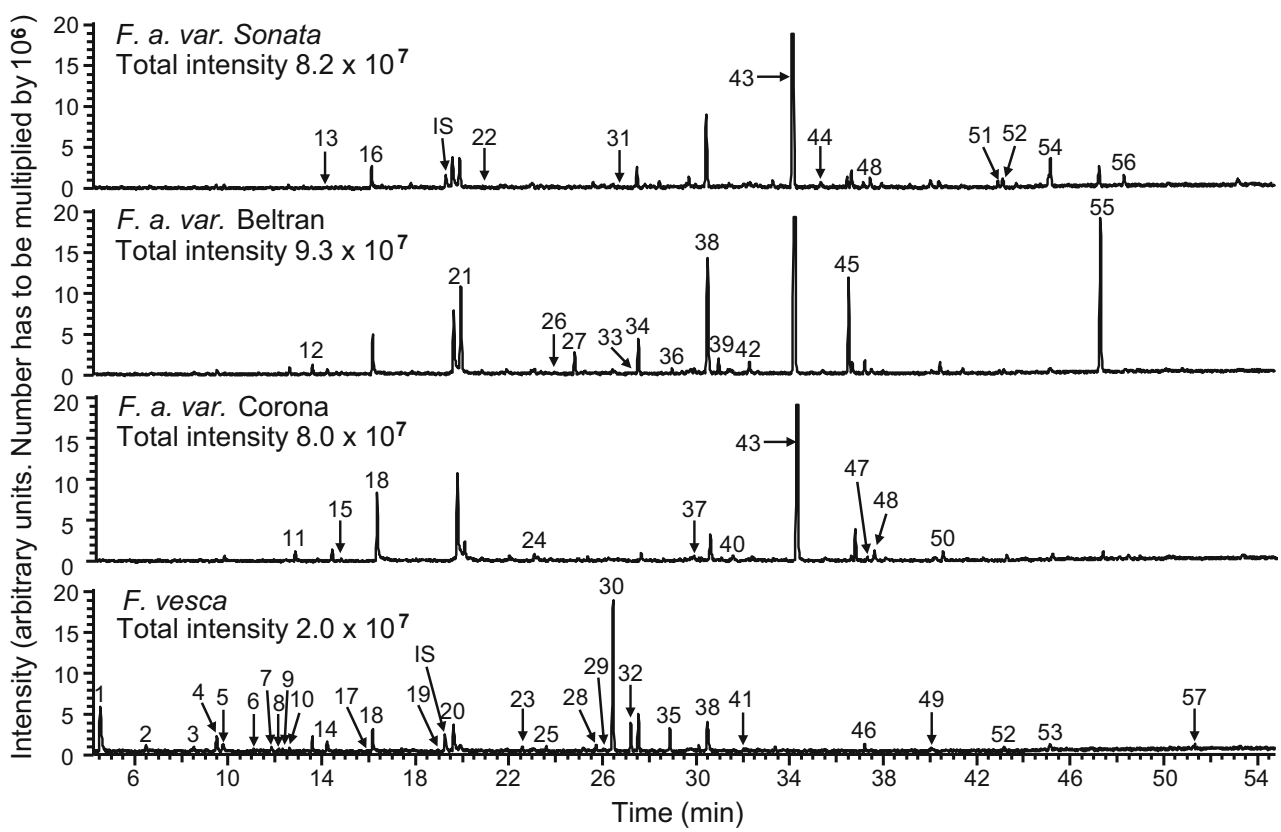

ananassa flower samples (Table 1). The odor blends of $F$. vesca flowers were characterized by seven unique compounds, including six terpenoids $[\alpha$-copaene (19), $\beta$ caryophyllene (23), 3,6,6-trimethyl-2-norpinanone (25), germacrene D (29), (3E,7E)-4,8,12- rimethyltrideca1,3,5,7,11-tetraene (TMTT) (35) and $\beta$-phellandrene (5)], as well as one alcohol [1,4-butanediol (41)]. Of the 24 compounds, 15 were terpenoids, three aromatics, three aldehydes, and one each of a ketone, ester and unidentified compound (Fig. 2, Table 1). Floral volatile blends from $F . x$ ananassa contained 17 unique compounds, including 10 aromatics, two terpenoids, one ketone and four unidentified compounds (Table 1).

The second MDS axis explained differences between $F$. vesca genotypes and some of the variation between $F . x$ ananassa varieties (Fig. 2). A significant correlation ( $\mathrm{r}=$
$0.5356, P=0.017$ ) (Fig. 3) was found between geographical separation of $F$. vesca genotypes and differences in floral odor blends, expressed as projection distances of blends on the second MDS axis in Fig. 2. Flowers of variety Sonata had the odor blend most distinct from the other two varieties of $F . x$ ananassa (Fig. 4), and were characterized by large amounts of benzyl alcohol (38), 3,4 dimethoxybenzaldehyde (51) and linalool (22). Odor blends of variety Korona were distinguished by larger amounts of $\beta$-phellandrene (5), (Z)-3-hexen-1-ol (17) and nonanal (18) and the absence of eight compounds compared to the other two cultivars (Table 1). (E)- $\beta$-Ocimene (7), 1ethenyl-4-methoxybenzene (27), (E,E)- $\alpha$-farnesene (32), an unidentified sesquiterpene (37) and $\beta$-pinene (29) were present in larger quantities in the odor blends of variety Beltran.
Fig. 2 Score plot of odor blends sampled by solid phase microextraction of headspace of single flowers of Fragaria $x$ ananassa varieties Sonata, Beltran, Korona, and Fragaria vesca potted plants. Roman numerals represent genotype of $F$. vesca plants; MDS $=$ multidimensional scaling

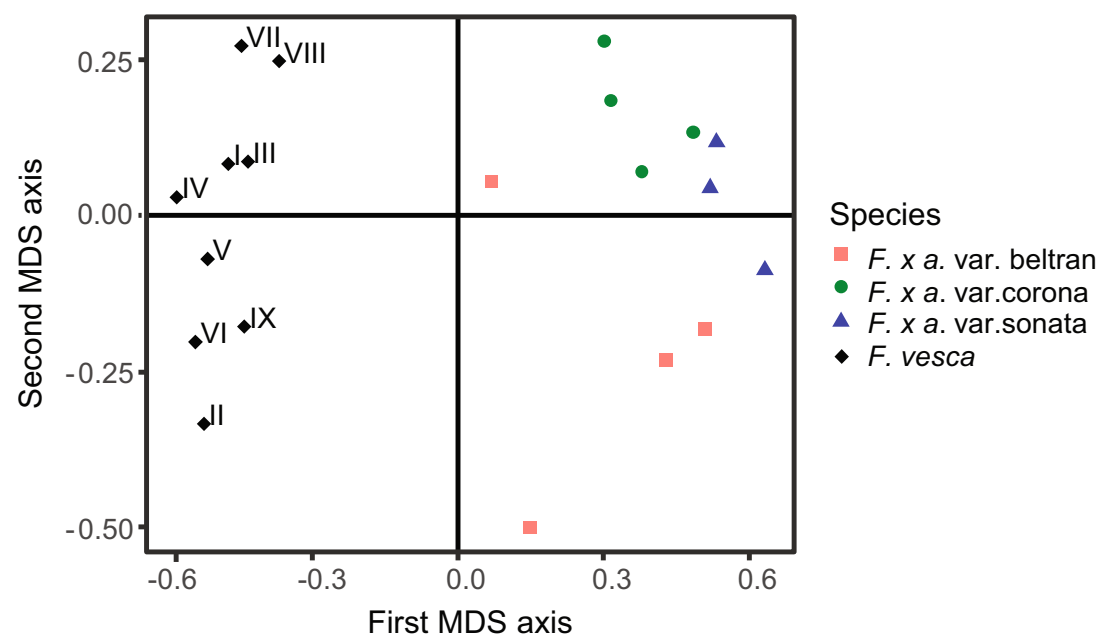




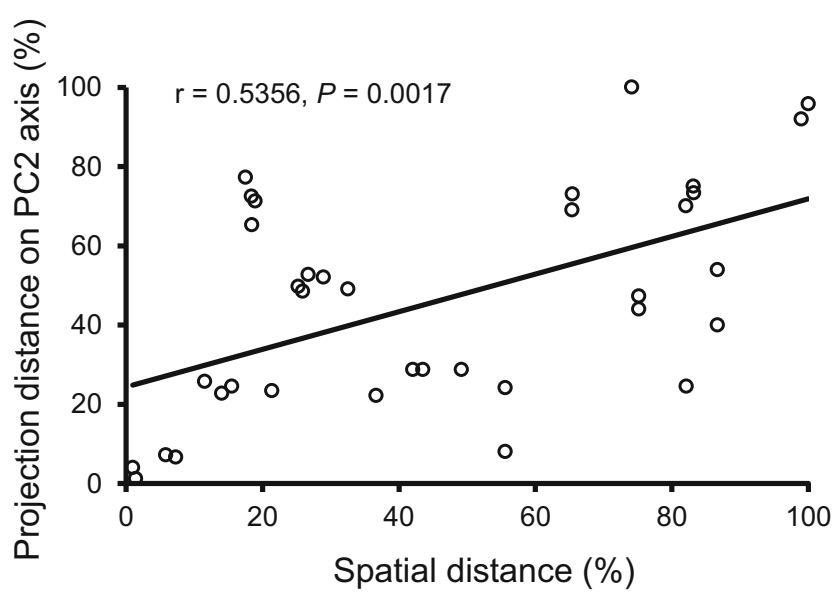

Fig. 3 Relationship between geographic separations of Fragaria vesca genotypes in the field and differences in floral odor blends expressed as projection distances of blends on the second axis in the multidimensional scaling score plot in Fig. 2. Both spatial and floral blend projection distances were transformed to percentage scale assigning the largest distance to $100 \%$. The largest spatial distance between origins of two genotypes was $95 \mathrm{~km}$

\section{Olfactory Preferences of Anthonomus rubi}

SBW showed no preference for either olfactometer arm when no olfactory cue was present, showing no inherent bias in the bioassay (Fig. 5b). When given the choice between odors of flowering $F . x$ ananassa var. Sonata plants and odors from non-flowering plants, both male and female SBW preferred those from the flowering plant $(N=16, Z=2.811, P=0.005$ and $N=14, Z=1.977, P=0.048$, respectively) (Fig. 5c). In further experiments, SBW were not separated by sex.

When testing SBW preference to odors of flowering versus non-flowering $F$. vesca, more weevils chose odors of flowering plants $(N=14, Z=2.068, P=0.041)$. No preference was observed between odors of flowering $F . x a$. var. Sonata and $F$. vesca plants $(N=11, Z=0.044, P=0.965)$ (Fig. $5 c)$.

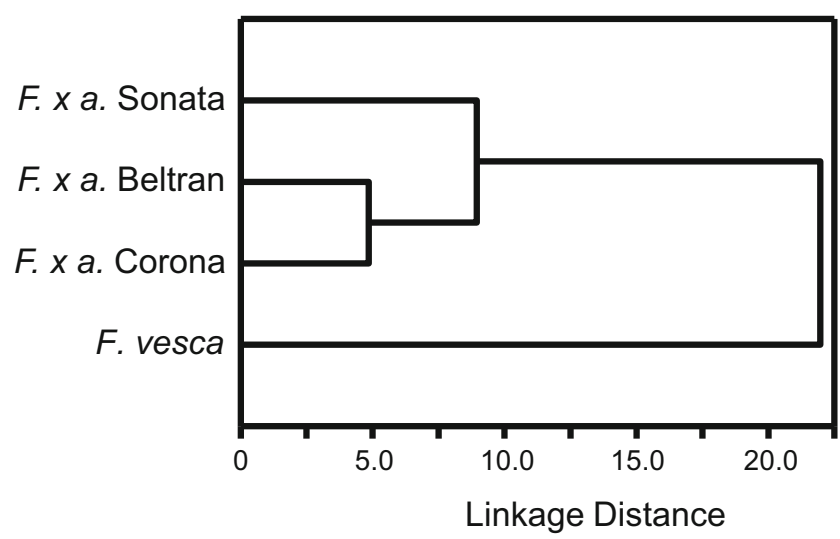

Fig. 4 Dendrogram of odor blends sampled by solid phase microextraction of headspace of single flowers of Fragaria x ananassa varieties Sonata, Beltran, Korona, and Fragaria vesca. Dendrogram was obtained by cluster analysis based on Euclidian distance. Numbers on $\mathrm{x}$ axis have to be multiplied by $10^{9}$
SBW preferred non-flowering $F$. $x a$. var. Sonata strawberry plants with the FAS synthetic odor blend (4methoxybenzaldehyde, benzaldehyde, benzyl alcohol, methyl salicylate, limonene and decanal) compared to nonflowering plants alone $(N=11, \mathrm{Z}=2.667, P=0.008)$. Similarly, SBW preferred non-flowering $F$. vesca plants with the FV blend ( $\alpha$-muurolene, benzaldehyde, benzyl alcohol, methyl salicylate, limonene and decanal) over flowering plants alone ( $N=12, Z=2.746, P=0.006)$ (Fig. 5d).

None of the compounds in the two blends when added individually at $100 \mathrm{ng}$ to non-flowering strawberry plants increased or decreased preference of SBW over non-flowering plants alone (benzaldehyde $N=11, \mathrm{Z}=1.156, P=0.248$; benzyl alcohol $N=10, \mathrm{Z}=1.376, P=0.169$; methyl salicylate $N=13, \mathrm{Z}=0.069, P=0.944 ; \alpha$-muurolene $N=14, \mathrm{Z}=$ $0.549, P=0.583$; limonene $N=6, Z=1.531, P=0.245$, and decanal $N=7, \mathrm{Z}=1.726, P=0.507$ ) (Fig. 5 d). Data on the effects of limonene and decanal should be considered preliminary due to the low number of replicates.

In the final bioassay experiment, SBW did not discriminate between odors released from non-flowering $F . x a$. var. Sonata strawberry plants and those from non-flowering plants of the same variety with added 4-methoxybenzaldehyde at $10 \mathrm{ng}$ or $100 \mathrm{ng}$ doses $(N=16, \mathrm{Z}=1.172, P=0.241$ and $N=12, \mathrm{Z}=$ $1.579, P=0.114$, respectively). When the dose was increased to $1000 \mathrm{ng}$, weevils preferred the side with the non-flowering plant alone ( $N=10, \mathrm{Z}=2.803, P=0.005)$ (Fig. 5e).

\section{Discussion}

\section{Chemical Composition and Variation of Strawberry Floral Odor Blends}

The composition of floral volatile emissions from several species of strawberry have been reported previously, including Fragaria x ananassa (Bichão et al. 2005a; Ceuppens et al. 2015; Hamilton-Kemp et al. 1990, 1993; Klatt et al. 2013), F. virginiana Duchesne (Ashman et al. 2005), F. vesca (Blažytė-Čereškienè et al. 2017; Wibe et al. 2014) and F. viridis Duchesne (Blažytė-Čereškienè et al. 2017). In those studies, static and dynamic headspace collections as well as hydro-distillation techniques were used to sample floral compounds from cut and intact flowers, making it difficult to compare data. The amounts of volatiles produced by individual strawberry flowers are very small; hence, we used SPME to sample volatile profiles under standardized conditions. This provided a highly sensitive technique able to detect more compounds than in the above studies, and also provided quantitative data for comparisons of varieties and species. Dynamic headspace sampling with an internal standard was also used for more reliable quantification of compounds and release rates. 
(a)

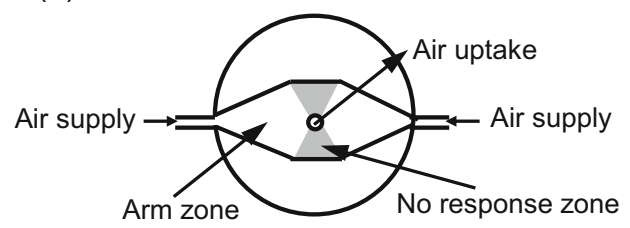

(b)

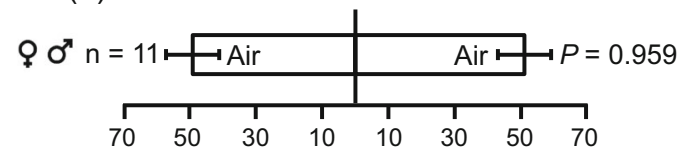

Mean number of the records in each arm (\%)

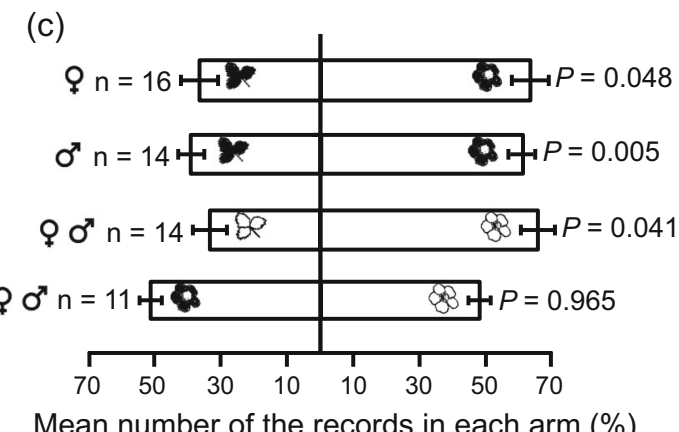

Mean number of the records in each arm (\%)

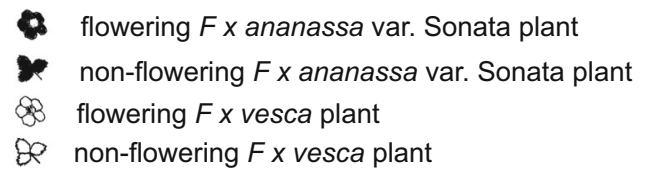

Fig. 5 a Schematic of two-choice olfactometer. Behavioral responses of Anthonomus rubi weevils in two-choice olfactometer to (b) air, $\mathbf{c}$ odors of flowering and non-flowering Fragaria x ananassa variety Sonata and $F$. vesca plants; $\mathbf{d}$ mixtures or single synthetic compounds, found in floral odors of $F$. $x a$. var. Sonata, $F$. vesca and Fragaria viridis; e three doses of 4-methoxybenzaldehyde. Vertical bars are SEM; $n=$ number of weevils tested; FAS is the six-component blend of 4-methoxybenzaldehyde,

We found that 4-methoxybenzaldehyde ( $p$-anisaldehyde) was the major constituent of the floral volatile blends released by all three $F$. $x$ ananassa varieties. This contrasts with previous reports in which benzaldehyde was present in the largest amount in volatile emissions of $F$. $x$ ananassa varieties Darselect, Honeoye (Klatt et al. 2013) and Korona (Bichão et al. 2005a). (E,E)- $\alpha$-Farnesene and limonene were reported as the major component of floral emissions of the variety Sonata by Klatt et al. (2013) and Ceuppens et al. (2015), respectively. In our study, these compounds were present at lower amounts in Sonata flowers. The reason for the quantitative differences in these studies is unknown.

In our study, $\alpha$-muurolene was the major component in volatiles from flowers of $F$. vesca. 1,4-Dimethoxybenzene was reported as the major constituent of $F$. vesca floral volatile

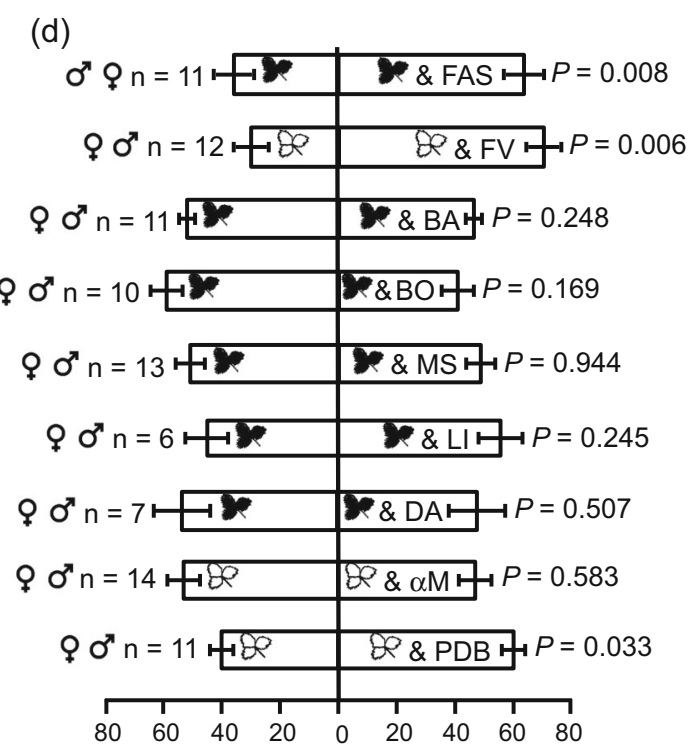

Mean number of the records in each arm (\%)

(e)

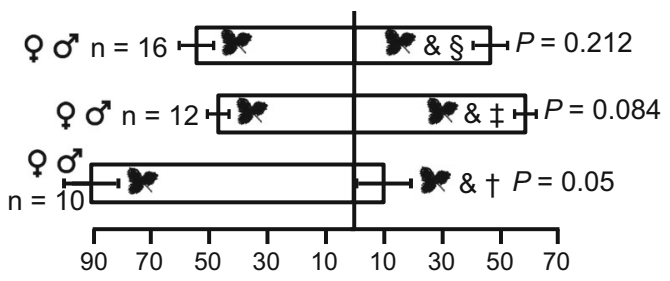

Mean number of the records in each arm (\%)

benzaldehyde (BA), benzyl alcohol (BO), methyl salicylate (MS), limonene (LI) and decanal (DA); FV is the six-component blend of $\alpha$ muurolene $(\alpha \mathrm{M}), \mathrm{BA}, \mathrm{BO}, \mathrm{MS}$, LI and $\mathrm{DA}$; $\mathrm{PDB}=1,4$ dimethoxybenzene. $\S, \$$ and $\dagger$ represent 4-methoxy-benzaldehyde at doses of 10, 100 and $1000 \mathrm{ng}$, respectively; Data were analyzed by nonparametric Wilcoxon matched-pairs signed-ranks test

emissions by Wibe et al. (2014), contributing $96.6 \%$ of the total amount. However, neither we nor Blažytė-Čereškienè et al. (2017) detected this compound in the blends released by $F$. vesca flowers. 1,4-Dimethoxybenzene was one of the major components present in samples of $F$. viridis flowers (Blažytė-Čereškienè et al. 2017), suggesting that Wibe et al. (2014) worked with other strawberry species or hybrids, rather than $F$. vesca.

The SPME data were used to carry out MDS analyses, which separated volatile blends released from $F$. x ananassa and $F$. vesca flowers. The analyses also explained differences between $F$. vesca genotypes, and partly explained the variation among the volatile blends from the three varieties of $F$. $x$ ananassa varieties. Flowers of variety Sonata had the most distinct odor blend. 
Single cell recordings had previously revealed 58 identified and a few unidentified compounds that elicited responses of SBW olfactory receptors (Bichão et al. 2005a, b). We detected 16 of these compounds in strawberry floral volatile emissions.

Despite the differences in composition of blends of volatiles from the flowers of different species and varieties of strawberry, there were at least 13 common compounds. Five of the most abundant were benzaldehyde, benzyl alcohol, methyl salicylate, limonene and decanal. These were combined with 4-methoxybenzaldehyde and $\alpha$-muurolene to give blends representative of $F$. $x$ ananassa (FAS) and $F$. vesca (FV), respectively, for testing in bioassays. All these compounds elicited electrophysiological responses from antennae of SBW (Bichão et al. 2005a).

\section{Olfactory Preferences of Anthonomus rubi}

Our data showed that SBW preferred odors of flowering strawberry over those of non-flowering plants. This was somewhat surprising, as SBW females oviposit in flower buds prior to opening. Possibly, floral volatiles are detected from the bud before opening, or weevils are attracted to the area by neighboring flowers which have already opened. A similar preference for odors released from flowering over nonflowering hosts was also reported for cranberry weevils, Anthonomus musculus Say (Szendrei et al. 2009), which have oviposition and feeding strategies similar to SBW. However, only female A. musculus showed preference to odor blends released by blueberry flowers over those of flower buds (Szendrei et al. 2009). In our study, we did not detect any sex differences in preference.

Addition of a six-component blends of chemicals to nonflowering plants of both cultivated $F$. $x$ ananassa var. Sonata and wild species $F$. vesca, increased attractiveness to SBW, relative to non-flowering plants alone. The FAS blend mimicking the blend from cultivated strawberry included 4methoxybenzaldehyde as the major component, while the major component in the FV blend mimicking wild strawberry was $\alpha$-muurolene. The other five components in these two synthetic blends were the same, consistent with the observation that SBW shows no preference for flowering plants of either species.

However, none of the compounds in the two sixcomponent blends increased the preference of SBW when tested as a single compound added to non-flowering plants. This indicates a synergistic action of the volatiles, a common phenomenon in insect behavioral responses to host plant volatiles (Bruce and Pickett 2011; Richards et al. 2016; Sarkar et al. 2017). Olfactory synergism between floral volatiles is less frequently reported compared to odors of vegetative plant parts, possibly due to the activity of individual floral components rarely having been examined (Metcalf et al. 1995; Richards et al. 2016).
4-Methoxybenzaldehyde, the major component of floral volatiles from $F$. $x$ ananassa, actually reduced the attractiveness of non-flowering plants when added at the highest dose of $1000 \mathrm{ng}$. A similar phenomenon was reported by Webster et al. (2010), showing that individual components of attractive blends of host-plant volatiles can have repellent activity when presented at higher than natural doses and outside the context of the natural host blend.

1,4-Dimethoxybenzene increased the attractiveness to SBW of non-flowering $F$. vesca plants when added as a single compound. This compound was previously identified as a major component of floral volatiles of $F$. viridis (BlažytèČereškienè et al. 2017; Wibe et al. 2014) and increased the attractiveness of SBW aggregation pheromone in field trials (Baroffio et al. 2018; Wibe et al. 2014). This provides encouragement that our bioassay results are relevant to the field. We plan to test the active blends from the bioassays for attractiveness to SBW and/or synergism of the aggregation pheromone in field trials.

Acknowledgements The research has been funded from the project "Softpest Multitrap" provided by the CORE Organic II Funding Bodies, being partners of the FP7 ERA-Net project, CORE Organic II (Coordination of European Transnational research in Organic Food and Farming systems, project no. 249667). We thank Sara Bruun and Birgitta Svensson for collecting the strawberry blossom weevils and Professor Johan A. Stenberg at Swedish University of Agricultural Sciences, Alnarp, Sweden for access to the collection of $F$. vesca genotypes.

Funding Open access funding provided by Stockholm University.

Open Access This article is licensed under a Creative Commons Attribution 4.0 International License, which permits use, sharing, adaptation, distribution and reproduction in any medium or format, as long as you give appropriate credit to the original author(s) and the source, provide a link to the Creative Commons licence, and indicate if changes were made. The images or other third party material in this article are included in the article's Creative Commons licence, unless indicated otherwise in a credit line to the material. If material is not included in the article's Creative Commons licence and your intended use is not permitted by statutory regulation or exceeds the permitted use, you will need to obtain permission directly from the copyright holder. To view a copy of this licence, visit http://creativecommons.org/licenses/by/4.0/.

\section{References}

Aasen SS, Trandem N (2006) Strawberry blossom weevil Anthonomus rubi Herbst (Col.: Curculionidae): relationships between bud damage, weevil density, insecticide use, and yield. J Pest Sci 79:169 174. https://doi.org/10.1007/s10340-006-0131-z

Aasen SS, Hàgvar EB, Trandem N (2004) Oviposition pattern of the strawberry blossom weevil Anthonomus rubi Herbst (Coleoptera: Curculionidae) in eastern Norway. Norw J Entomol 51:175-182

Alford DV (1984) A colour atlas of fruit pests - their recognition, biology and control. Wolfe Publishing Ltd., London

Ashman TL, Bradburn M, Cole DH, Blaney BH, Raguso RA (2005) The scent of a male: the role of floral volatiles in pollination of a gender 
dimorphic plant. Ecology 86:2099-2105. https://doi.org/10.1890/ 04-1161

Baroffio CA, Sigsgaard L, Ahrenfeldt EJ, Borg-Karlson AK, Bruun SA, Cross JV, Fountain MT, Hall D, Mozuraitis R, Ralle B, Trandem N, Wibe A (2018) Combining plant volatiles and pheromones to catch two insect pests in the same trap: examples from two berry crops. Crop Prot 109:1-8. https://doi.org/10.1016/j.cropro.2018.02.025

Bichão H, Borg-Karlson A-K, Araújo J, Mustaparta H (2005a) Five types of olfactory receptor neurons in the strawberry blossom weevil Anthonomus rubi: selective responses to inducible host-plant volatiles. Chem Senses 30:153-170. https://doi.org/10.1093/chemse/ bji012

Bichão H, Borg-Karlson A-K, Wibe A, Araújo J, Mustaparta H (2005b) Molecular receptive ranges of olfactory receptor neurones responding selectively to terpenoids, aliphatic green leaf volatiles and aromatic compounds, in the strawberry blossom weevil Anthonomus rubi. Chemoecology 15:211-226. https://doi.org/10. 1007/s00049-005-0315-7

Blažytė-Čereškienė L, Apšegaitė V, Būda V (2017) Flower VOCs' perception: specialization sign in generalist pollinator. The joint meeting of the 33rd annual meeting of the ISCE and the 9th meeting of APACE, Ryukoku University, Kyoto, Japan P.194 (S1-P-008)

Bruce TJA, Pickett JA (2011) Perception of plant volatile blends by herbivorous insects - finding the right mix. Phytochemistry. 72: 1605-1611. https://doi.org/10.1016/j.phytochem.2011.04.011

Ceuppens B, Ameye M, Van Langenhove H, Roldan-Ruiz I, Smagghe G (2015) Characterization of volatiles in strawberry varieties 'Elsanta' and 'Sonata' and their effect on bumblebee flower visiting. Arthropod-Plant Interact 9:281-287. https://doi.org/10.1007/ s11829-015-9375-y

Cross JV, Easterbrook MA, Crook AM, Crook D, Fitzgerald JD, Innocenzi PJ, Jay CN, Solomon MG (2001) Review: natural enemies and biocontrol of pests of strawberry in northern and Central Europe. Biocontrol Sci Techn 11:165-216. https://doi.org/10.1080/ 09583150120035639

Cross JV, Hesketh H, Jay CN, Hall DR, Innocenzi PJ, Farman DI, Burgess CM (2006a) Exploiting the aggregation pheromone of strawberry blossom weevil Anthonomus rubi Herbst (Coleoptera : Curculionidae): part 1. Development of lure and trap. Crop Prot 25: 144-154. https://doi.org/10.1016/j.cropro.2005.04.002

Cross JV, Hall DR, Innocenzi PJ, Hesketh H, Jay CN, Burgess CM (2006b) Exploiting the aggregation pheromone of strawberry blossom weevil Anthonomus rubi Herbst (Coleoptera : Curculionidae): part 2. Pest monitoring and control. Crop Prot 25:155-156. https:// doi.org/10.1016/j.cropro.2005.04.004

Dickens JC (1989) Green leaf volatiles enhance aggregation pheromone of the boll weevil Anthonomus grandis. Entomol Exp Appl 52:191203. https://doi.org/10.1111/j.1570-7458.1989.tb01268.x

Easterbrook MA, Fitzgerald JD, Pinch C, Tooley J, Xu X-M (2003) Development times and fecundity of three important arthropod pests of strawberry in the United Kingdom. Ann Appl Biol 143:325-331. https://doi.org/10.1111/j.1744-7348.2003.tb00301.x

Hambäck PA, Pettersson J, Ericson L (2003) Are associational refuges species-specific? Funct Ecol 17:87-93. https://doi.org/10.1046/j. 1365-2435.2003.00699.x

Hamilton-Kemp TR, Loughrin JH, Andersen RA (1990) Identification of some volatile compounds from strawberry flowers. Phytochemistry 29:2847-2848. https://doi.org/10.1016/0031-9422(90)87089-D

Hamilton-Kemp TR, Loughrin JH, Andersen RA, Rodriguez JG (1993) Volatile compounds from strawberry foliage and flowers - air versus nitrogen entrainment - quantitative changes and plant development. ACS Symp Ser 525:229-239
Hill DS (1987) Agricultural insect pests of temperate regions and their control. Cambridge University Press, Cambridge

Innocenzi PJ, Hall DR, Cross JV (2001) Components of the male aggregation pheromone of strawberry blossom weevil, Anthonomus rubi Herbst. (Coleoptera: Curculionidae). J Chem Ecol 27:1203-1218

Innocenzi PJ, Hall DR, Cross JV, Green SV (2002) Sexing adults of the strawberry blossom weevil, Anthonomus rubi (Col., Curculionidae). J Appl Entomol 126:159-160. https://doi.org/10.1046/j.1439-0418. 2002.00610.x

Jary BA (1931) A note on the strawberry and raspberry bud weevil, Anthonomus rubi (Herbst). J S-E Agric Coll Wye, Kent 28:147-152

Klatt BK, Burmeister C, Westphal C, Tscharntke T, von Fragstein M (2013) Flower volatiles, crop varieties and bee responses. PLoS One 8:e72724. https://doi.org/10.1371/journal.pone.0072724

Kovanci OB, Kovanci B, Gencer NS (2005) Sampling and development of economic injury levels for Anthonomus rubi Herbst adults. Crop Prot 24:1035-1041. https://doi.org/10.1016/j.cropro.2005.02.007

Krauß A, Steen C, Zebitz CPW (2014) Phenology of the strawberry blossom weevil and damage in strawberries. 16th International conference on organic fruit-growing. Stuttgart-Hohenheim, pp 32-236.

Labanowska BH (2004) Flower bud damage in twenty strawberry cultivars by the strawberry blossom weevil - Anthonomus rubi Herbst. J Fruit Ornam Plant Res 12:113-118

Leska W (1965) Badania nad biologia i szkodliwoscia kwieciaka malinowca Anthonomus rubi Hbst. (Col: Curculionidae). Polskie Pismo Entomologiczne (B) 1-2:18-142

Metcalf RL, Lampman RL, Deem-Dickson L (1995) Indole as an olfactory synergist for volatile kairomones for Diabroticite beetles. J Chem Ecol 21:1149-1162. https://doi.org/10.1007/BF02228317

Millar JG, Haynes KF (1998) Methods in chemical ecology, chemical methods. Kluwer Academic Publishers, Boston

Muniz-Merino M, Cibrian-Tovar J, Hidalgo-Moreno C, BautistaMartinez N, Vaquera-Huerta H, Aldama-Aguilera C (2014) Volatile compounds attract the pepper (Capsicum spp.) weevil (Anthonomus eugenii Cano) and synergize its aggregation pheromone. Agrociencia 48:819-832

Popov SY (1995) Possibility of monitoring the population density of the strawberry blossom weevil, Anthonomus rubi Herbst (Coleoptera, Curculionidae), on strawberry by using two methods: counting clipped buds and using pheromones. Entomol Rev (Russian edition) 74:753-757

Popov SY (1996) Trophical relations of the strawberry blossom weevil Anthonomus rubi Herbst (Coleoptera, Curcolionidae). Entomol Rev (Russian edition) 75:263-272

Reddy GVP, Guerrero A (2004) Interactions of insect pheromones and plant semiochemicals. Trends Plant Sci 9:253-261. https://doi.org/ 10.1016/j.tplants.2004.03.009

Richards LA, Glassmire AE, Ochsenrider KM, Smilanich AM, Dodson CD, Jeffrey CS, Dyer LA (2016) Phytochemical diversity and synergistic effects on herbivores. Phytochem Rev 15:1153-1166. https://doi.org/10.1007/s11101-016-9479-8

Rout PK, Rao YR, Naik S (2012) Analysis of floral volatiles by using headspace-solid phase microextraction: a review. Asian J Chem 24: 945-956

Sarkar N, Mitra S, Barik A (2017) Momordica charantia L. (Cucurbitaceae) floral volatiles causing attraction of Epilachna dodecastigma (Coleoptera: Coccinellidae). Int J Pest Manage 63: $138-145$

SPME guidelines (2020) https://static.springer.com/sgw/documents/ 874338/application/pdf/SPME\%20Guidelines.pdf. Accessed 4 Apr 2020.

Suckling DM, Stringer LD, Stephens AEA, Woods B, Williams DG, Baker G, El-Sayed AM (2014) From integrated pest management 
to integrated pest eradication: technologies and future needs. Pest Manag Sci 70:179-189. https://doi.org/10.1002/ps.3670

Svensson B (2002) Organic growing of strawberries, with control of insects and mulching/ fertilization. Acta Hortic 567:419-422

Szendrei Z, Malo E, Stelinski L, Rodriguez-Saona C (2009) Response of cranberry weevil (Coleoptera: Curculionidae) to host plant volatiles. Environ Entomol 38:861-869. https://doi.org/10.1603/022.038. 0340

Vas G, Vekey K (2004) Solid-phase microextraction: a powerful sample preparation tool prior to mass spectrometric analysis. J Mass Spectrom 39:233-254. https://doi.org/10.1002/jms.606

Webster B, Bruce T, Pickett J, Hardie J (2010) Volatiles functioning as host cues in a blend become non-host cues when presented alone to the black bean aphid. Anim Behav 79:451-457. https://doi.org/10. 1016/j.anbehav.2009.11.028

Wibe A, Borg-Karlson A-K, Cross J, Bichao H, Fountain M, Liblikas I, Sigsgaard L (2014) Combining 1,4-dimethoxybenzene, the major flower volatile of wild strawberry Fragaria vesca, with the aggregation pheromone of the strawberry blossom weevil Anthonomus rubi improves attraction. Crop Prot 64:122-128. https://doi.org/10. 1016/j.cropro.2014.06.016

Yew JY, Chung H (2015) Insect pheromones: an overview of function, form, and discovery. Prog LipidRes 59:88-105. https://doi.org/10. 1016/j.plipres.2015.06.001 